\title{
Pope condemns 'immoral' embryo research
}

Paris. In the strongest condemnation so far by the Roman Catholic Church of the ethical risks associated with modern medicine, Pope John Paul II last week condemned embryo research, medically assisted procreation and the use of prenatal diagnosis for achieving 'eugenic' ends as immoral.

The Pope's declaration comes at a time when bioethics legislation is being drafted by several countries. It seems likely to fuel debate about both the influence of the Church in this area, and the extent to which medical progress should be regulated either by society as a whole or by the conscience of individual physicians and researchers.

In his eleventh encyclical, Evangelium Vitae - 'The Gospel of Life' - the Pope reaffirms that human life begins at the moment of fertilization, and that absolute respect should be given to all forms of human life. The statement vigorously condemns abortion, euthanasia and artificial contraception, and prohibits in vitro fertilization because of the associated death of supernumerary embryos.

The authorization of euthanasia in the Netherlands is thought to have prompted the Pope to speak out, as he considers it the beginning of a slippery slope. Similarly, while the Pope "upholds as licit" manipulations of embryos aimed at healing rather than harming, he condemns research on embryos as a "crime against their dignity as human beings", and the use of embryos as a source of tissues and organs for transplants as "absolutely unacceptable".

The Vatican statement accepts prenatal diagnosis as a means for early therapy, or in order to "favour a serene and informed acceptance" of the child not yet born. But it condemns as a "shameful and utterly reprehensible" the eugenic goal of using prenatal diagnosis to allow abortion of fetuses suffering from abnormalities.

Such so-called 'genetic reductionism' the tendency to stigmatize, ostracize or eliminate those not meeting a genetic norm - also emerged as the biggest threat from genome research at a recent meeting of UNESCO's International Bioethics Committee (see Nature 371, 369; 1994).

While the Church's reaffirmation that life begins at fertilization will continue to provoke vigorous controversy, Jean-François Mattei, professor of paediatrics and medical genetics at the University of Marseille in France, says that this issue is "philosophical and theological".

\section{IMAGE UNAVAILABLE FOR COPYRIGHT REASONS}

Pope John Paul II: the encylical reaffirms the Roman Catholic Church's opposition to embryo research.

"However you look at it, human embryos are fundamentally different from animal embryos", says Mattei, who claims that the real issue is about how society should incorporate moral issues into legislation.

France, which last year became the first country to introduce comprehensive bioethics legislation, shows how this issue can work out in practice. Mattei - who as a member of the French parliament strongly influenced the shape of the bioethics legislation - says that a basic principle is that a secular state cannot adopt a moral order where some impose their truth on others.

The Pope's stance represents only "Roman Catholic decisions about the Catholic faith aimed at Catholics," says
Mattei. He argues that morality and law have different roles to play. "But how can we choose between the possible, the desirable, and the forbidden without reference to moral, philosophical and religious values? If we have made much progress in acquiring knowledge, we have forgotten wisdom for too long."

Mattei and others also argue that decisions about the use of new medical techniques cannot be left to the conscience of researchers and physicians, as the ڤै. "anarchy" of individual demands ¿ for example, by patients - can "fundamentally modify the structure and evolution of society". Society, therefore, has a duty to provide legislation on such issues, says Mattei. He argues that "we cannot remain powerless in the face of aberrations that pervert progress".

The French bioethics legislation reaffirms the fundamental values of human dignity and the respect for other human beings from the beginning of life. At the same time, Mattei says the legislation is "realistic" in recognizing that exceptions need to be allowed.

The French parliament rejected attempts by the French senate, for example, to ban all research on human embryos, preimplantation diagnosis, and the destruction of supernumerary embryos produced in in vitro fertilization procedures.

This followed a vigorous debate in the French research and medical communities. Many participants, while divided on the real justification for much embryo research, argued that a "margin of liberty" should be given to the conscience of researchers and physicians. Similarly, the arguments of physicians that preimplantation diagnosis should be allowed for a defined list of very serious diseases was also accepted.

Declan Butler

\section{Russian scientists struggle on against cuts in funding}

Moscow. Yuri Osipov, the president of the Russian Academy of Sciences (RAS), , said last week that for the first time in recent years there had been signs of stabilization in Russian science in 1994, reflected in the fall in the number of scientists of only 1.5 per cent compared to 4.5 per cent in 1992 and 3.6 per cent in 1993.

Osipov also said that although 1994 had been "a year of constant struggle and unfounded hopes", the academy had managed to maintain its integrity and "to remain the main centre of fundamental science in the state".

Addressing the academy's annual meeting in Moscow, he said the academy's successes in 1994 had included the development of computers capable of running at more than 2 billion operations a second, and a new method of cancer therapy, using a combination of two harmless substances which, once targeted on a cancer cell, form free radicals that destroy it.

Osipov and other speakers also pointed out that the academy had been less affected by cuts in government spending than other sectors of the economy. In 1994 the academy had received 75 per cent of the amount originally planned through the Ministry of Science and Technical Policy, while the allocations to other departments had been as low as 33 per cent.

Nevertheless, he described the way that the research money was used as "distorted", in that 48 per cent was spent directly on salaries, 35 per cent for electricity and government taxes, and only 17 per cent was spent directly on research.

Osipov confirmed that a lack of funding had meant that only one tenth of the scientific journals previously available can now be found in the research libraries, and that the academy had lost almost 3 billion rubles deposited in a bank that had subsequently collapsed. Carl Levitin 